\title{
The Effects of Drought Stress on Yield, Yield Components, and Yield Stability at Different Growth Stages in Bread Wheat Cultivar (Triticum aestivum L.)
}

\author{
Asghar Mehraban ${ }^{1 *}$, Ahmad Tobe ${ }^{1}$, Abdolghayoum Gholipouri ${ }^{1}$, Ebrahim Amiri², \\ Abdolali Ghafari ${ }^{3}$, Mozffar Rostaii ${ }^{4}$ \\ ${ }^{1}$ University of Mohaghegh Ardabili, Ardebil, Iran \\ ${ }^{2}$ Department of Water Engineering, Islamic Azad University, Lahijan Branch, Lahijan, Iran \\ ${ }^{3}$ Dryland Agricultural Research Institute (DARI), AREEO, Maragheh, Iran \\ ${ }^{4}$ West Azarbaijan Agricultural and Natural Resources Research and Education Center, AREEO, Urmia, Iran
}

Received: 15 December 2017

Accepted: 15 February 2018

\begin{abstract}
The current study examined the response of yield, yield components, and other physiological traits to drought in bread wheat. A field experiment was conducted in 2013-2015 at the the Agriculture and environmental research center of Ardabili located in Moghan, Iran. The experimental design was a splitplot experiment based on randomized complete block design with three replications under five drought stress (no irrigation) regimes: rainfed (T1), tillering stage (T2), booting stage (T3), after anthesis (T4), full irrigation (T5), and 10 bread wheat cultivars. Combined analysis of variance revealed significant genotypic differences for all measured trait aspects of TN, FTN, SN, and TDM. Significant differences were also observed between drought treatments for PH, DHE, DMA, GFP, NGS, TGW, HI, SW, TDM, GWP, and GW. The interaction between stress treatments and cultivars was also significant for DHE, DMA, GFP, NGS, TGW, and GY. The stability measuring of the GGE biplot polygon showed that the performance of cultivars G3, G7, and G8 are highly variable (less stable), whereas cultivars G5, G1, G2, G10, G9, and G4 are highly stable. Cultivars G9 and G10 are more desirable than other cultivars that has both high mean yield and high stability.
\end{abstract}

Keywords: drought stress, yield, bread wheat, stability, GGE biplot

\section{Introduction}

Bread wheat (Triticum aestivum L.) is one of the most important cereal crops in the development of humans.

*e-mail: asgharmehraban@gmail.com
Wheat, with about a 2.1 million $\mathrm{km}^{2}$ total harvested area, is the most abundant crop in the world: it is the first rain-fed crop after maize and the second irrigated crop after rice [1]. With a total production that surpassed 700 million tons (MTons) in 2010, it is contributing to about the $20 \%$ of the total dietary calories and proteins worldwide [2, 3]. Compared to other important crops, 
the main wheat producing regions are characterized by 'close-to-average' yield variability [4]. In Iran, cultivation of wheat has reached about 7.3 million hectares, with total production of about 14.5 million tons and average productivity of about 2 tons per hectare [5]. In most regions of Iran, wheat is produced under dry land, and in low rainfall regions of Iran supplemental irrigation is necessary. Drought is the single largest abiotic stress factor leading to reduced crop yields, so high-yielding crops even in environmentally stressful conditions are essential [6]. This stress is one of the most important threatening factors for the production of crop plants in the arid and semi-arid regions of the world. Understanding plant responses to drought is of great importance and also a fundamental part of making crops stress tolerant [7]. Drought stress has a considerable impact on plant growth, although the ranges of reductions are highly variable due to differences in the timing and intensity of the stress imposed and cultivar used [8].

Notwithstanding the possible need for phenological adjustment (earliness), a higher yield potential may also translate into higher performance under water stress [9, 10]. However, the potential yield and water-limited yield of wheat needs to continue increasing in order to cope with future demand for food, which is a consequence of the growing population and changes in social habits [9]. Bread wheat requires a minimum of 450-650 $\mathrm{mm}$ of rainfall in the growing season. Iran is located on the world's desert belt, and is considered an arid and semiarid region. Average rainfall in the country is about $250 \mathrm{~mm}$, which is one third of average rainfall in the world. Agricultural drought is the lack of ample moisture required for normal plant growth and development to complete the life cycle [11]. Plant responses to drought stress are very complex and include adaptive changes or deleterious effects. Drought affects morphology, growth, and metabolism of plants, and limits grain yield in most plants. The main consequences of drought in crop plants are reduced rate of cell division and expansion, leaf size, stem elongation, and root proliferation, and disturbed stomatal oscillations, plant water, and nutrient relations with diminished crop productivity [12]. To cope with such challenges, understanding the effects of drought on plants and morphological and physiological adaptations is crucial. The development of crop plants tolerant to drought stress might be a promising approach, which helps in meeting food demands.

The susceptibility of plants to drought varies in dependence of stress degree, different accompanying stress factors, plant species, and their developmental

Table 1. Agro-climatic characteristics of testing environment.

\begin{tabular}{|c|c|c|c|c|c|c|c|c|c|}
\hline \multirow{2}{*}{ Month } & \multirow{2}{*}{ Year } & \multicolumn{3}{|c|}{$\operatorname{Temp}\left({ }^{\circ} \mathrm{C}\right)$} & \multirow{2}{*}{$\begin{array}{l}\text { Rainfall } \\
\text { (mm) }\end{array}$} & \multirow{2}{*}{$\begin{array}{l}\text { Average Humidity } \\
\qquad(\%)\end{array}$} & \multirow{2}{*}{$\begin{array}{l}\text { Evaporation } \\
\qquad(\mathrm{MM})\end{array}$} & \multirow{2}{*}{\multicolumn{2}{|c|}{ Soil Condition }} \\
\hline & & Min & Max & Mean. & & & & & \\
\hline \multirow{2}{*}{ Sep. } & 2013-14 & 15.5 & 30.0 & 22.7 & 19.0 & 68.2 & 165.8 & \multirow{3}{*}{ Texture } & \multirow{3}{*}{ Sandy-Loam-Silt } \\
\hline & 2014-15 & 17.7 & 29.1 & 23.4 & 25.4 & 64.9 & 160.5 & & \\
\hline \multirow{2}{*}{ Oct. } & 2013-14 & 9.7 & 20.6 & 15.15 & 29.7 & 75 & 67.2 & & \\
\hline & 2014-15 & 10.5 & 18.7 & 14.6 & 1.6 & 78.0 & 42 & \multirow{3}{*}{$\%$ Silt } & \multirow{3}{*}{14} \\
\hline \multirow{2}{*}{ Nov. } & 2013-14 & 6.3 & 15.7 & 11.1 & 75.0 & 80 & 21.1 & & \\
\hline & 2014-15 & 5.4 & 12.9 & 9.2 & 46.8 & 79.1 & 12.3 & & \\
\hline \multirow{2}{*}{ Dec. } & $2013-14$ & -0.9 & 6.7 & 2.9 & 18.3 & 74 & 0 & \multirow{3}{*}{$\%$ Loam } & \multirow{3}{*}{57} \\
\hline & 2014-15 & 2.6 & 10.5 & 6.5 & 5.3 & 81.3 & 0 & & \\
\hline \multirow{2}{*}{ Jan. } & $2013-14$ & -0.6 & 10.7 & 5 & 7.8 & 70 & 0 & & \\
\hline & 2014-15 & 0.6 & 8.2 & 4.4 & 5.8 & 80.3 & 0 & \multirow{3}{*}{$\%$ Sandy } & \multirow{3}{*}{29} \\
\hline \multirow{2}{*}{ Feb. } & $2013-14$ & -0.7 & 9.5 & 4.4 & 89.0 & 74 & 0 & & \\
\hline & 2014-15 & 1.9 & 10.6 & 6.3 & 21.9 & 79.2 & 0 & & \\
\hline \multirow{2}{*}{ Mar. } & $2013-14$ & 4.7 & 15.7 & 20.4 & 51.3 & 70 & 0 & \multirow{2}{*}{$\mathrm{pH}$} & \multirow{2}{*}{7.9} \\
\hline & 2014-15 & 4.4 & 12.7 & 8.5 & 14.9 & 79.8 & 2.6 & & \\
\hline \multirow{2}{*}{ Apr. } & 2013-14 & 8 & 20.9 & 14.4 & 22.9 & 68 & 72 & \multirow{2}{*}{$\% \mathrm{~N}$} & \multirow{2}{*}{0.01} \\
\hline & 2014-15 & 7.7 & 19.1 & 13.4 & 11.9 & 71.5 & 86.3 & & \\
\hline \multirow{2}{*}{ May. } & 2013-14 & 15.5 & 29.4 & 22.4 & 31.1 & 66 & 170 & \multirow{4}{*}{$\% \mathrm{C}$} & \multirow{4}{*}{0.98} \\
\hline & $2014-15$ & 14.0 & 26.7 & 20.3 & 11.6 & 68.2 & 121.5 & & \\
\hline \multirow{2}{*}{ Jun. } & 2013-14 & 18.4 & 33.1 & 25.7 & 37.2 & 52 & 232.9 & & \\
\hline & $2014-15$ & 17.5 & 32.6 & 25.0 & 37.2 & 59.6 & 338.3 & & \\
\hline
\end{tabular}


stages [13, 14]. Water deficiency during different developmental stages can change the values of yield components $[15,16]$. Drought stress reduces grain yield of wheat through negative affecting the yield components, i.e., number of plants per unit area, number of spikes and grains per plant, or unit area and single grain weight, which are determined at different stages of plant development [17, 15-16]. In other words, water deficiency in different stages of plant growth can have different effects on physiological and morphological traits. Therefore, the objective of our study was to determine whether the timing of the drought stress in plant development affects yield and other morphological and physiological traits in bread wheat. The current study examined the response of yield, yield components, and other physiological traits to drought occurring in bread wheat plants at five different developmental stages.

\section{Material and Methods}

\section{Experimental Site and Treatments}

A field experiment was conducted through subjecting the bread wheat cultivar to five levels of moisture stress in 2013-2015 at the experimental farm of the Agriculture and Environmental Research Center of Ardabili in Moghan, Iran $\left(39^{\circ} 39^{\prime} \mathrm{N}, 48^{\circ} 16^{\prime} \mathrm{E}\right.$ and $32 \mathrm{~m}$ a.s.l.). Agro-climatic characteristics of testing environments is given in Table 1. The field experimental design was a split-plot experiment based on randomized complete block design with three replications under five contrasting irrigation regimes. The cultivar was developed by various breeders at different research institutes/stations of Iran and International Maize and Wheat Improvement Center (CIMMYT). The names, cultivars, codes, and origins of these cultivars are given in Table 2. Drought stresses (no irrigation) were introduced: rainfed (T1), the tillering stage (35 days after sowing) (T2), at booting stage (60 days after sowings) (T3), and after anthesis (T4). At the control treatment (T5), soil moisture was maintained at the optimal level. The drought stress was maintained in the range of limited water availability and always above permanent wilting point, except for rainfed (T1).

The experimental plot consisted of six rows $6 \mathrm{~m}$ long with $0.2 \mathrm{~m}$ spacing between rows, which resulted in a plot area of $7.2 \mathrm{~m}^{2}$ and a seed rate of 350 seeds $/ \mathrm{m}^{2}$ for each treatment. Based on a soil test before planting, 50 and $100 \mathrm{~kg} \mathrm{ha}^{-1}$ of urea and $\mathrm{P}_{2} \mathrm{O}_{5}$ were applied, respectively. Weed control was conducted with an application of the herbicide 2-4-D at $1.0 \mathrm{Li}^{-\mathrm{ha}^{-1}}$.

At the end of the experiment, data on grain yield were taken from the middle four rows of each plot, leaving aside the guard rows on either side of the plot. For measured agronomical traits we selected 10 plants as a simple per plot, and recorded the traits that included: total plant weight (TPW in g) as the total weight of straw and grain weight harvested from samples; grain weight (GW in $\mathrm{g}$ )
Table 2. Cultivar codes and name of 10 bread wheat cultivars.

\begin{tabular}{|c|c|c|}
\hline Cultivars codes & Name & Origin \\
\hline $\mathrm{C} 1$ & Zagros & Iran \\
\hline $\mathrm{C} 2$ & Karim & Iran \\
\hline $\mathrm{C} 3$ & Kohdasht & CIMMYT \\
\hline $\mathrm{C} 4$ & Seymareh & CIMMYT \\
\hline $\mathrm{C} 5$ & Dehdasht & Iran \\
\hline $\mathrm{C} 6$ & Niknejad & CIMMYT \\
\hline $\mathrm{C} 7$ & Aftab & Iran \\
\hline $\mathrm{C} 8$ & Gaboss & Iran \\
\hline $\mathrm{C} 9$ & Chmran & CIMMYT \\
\hline $\mathrm{C} 10$ & Shirodi & CIMMYT \\
\hline
\end{tabular}

as the weight of harvested grains from samples; straw weight (SW in g) was obtained by subtracting GW from TPW; grain number (GN) as the total number of grains counted from spikes in any samples; thousand kernel weight (TKW in g) as the weight of one thousand kernels; fertile tiller number (FTN) as the final number of tillers have spikes counted from each plant; and harvest index (HI as a percentage) calculated by dividing GW by TPW, multiplied by 100 .

\section{Statistical Analysis}

Data were analyzed using SAS Version 9.16 [18]. Significant differences among cultivars were determined using LSD at probability $=0.05$. The GGE-biplot software [54] was used for studying relationship traits and selecting drought-tolerant cultivars.

\section{Results and Discussion}

Combined analysis of variance of the 10 bread wheat cultivars revealed (Table 3) significant genotypic differences for all measured trait aspects of TN, FTN, $\mathrm{SN}$, and TDM. Significant differences were also observed between drought treatments applied on the 10 cultivars for PH, DHE, DMA, GFP, NGS, TGW, HI, SW, TDM, GWP, and GW in five conditions, while there was no significant difference between TN, FTN, and SN (Table 3). The interaction between stress treatments and cultivars was also significant for DHE, DMA, GFP, NGS, TGW, and GY. There were year effects for PH, DHE, DMA, GFP, SN, TGW, TDM, GWP, and GY. The year $\times$ irrigation interaction was statistically significant for DHE, DMA, and GFP.

Days to heading was determined as the number of days from planting to the date when $50 \%$ of the heads in the plot were completely emerged. Days to heading was different among five irrigation regimes $(\mathrm{P}<0.01)$, ranging from 133 to $155 \mathrm{~d}$ and from 140 to $156 \mathrm{~d}$ after 


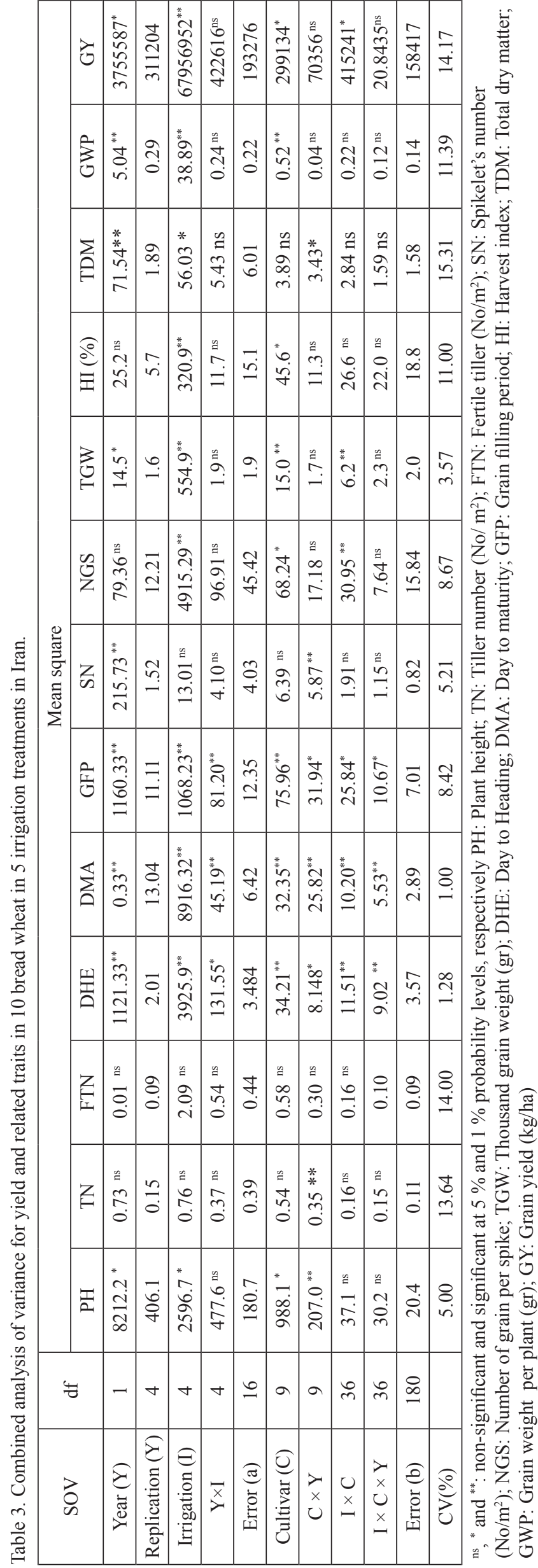

sowing for 2013 and 2014 seasons, respectively. High variations in DHE were also observed among cultivars. Dry land cultivar (G1, G2, G3, G4, G5, and G6) required the shortest period of days to heading and maturity while other cultivars (G7, G8, G9, and G10) required the longest period. Cultivars G4 showed the earliest DMA, while G10 was the latest across all irrigation regimes. The effects of drought stress on the flowering time irrespective of cultivar showed that stress at irrigation conditions (T5) caused a delay in heading time when compared to stress conditions. The studies showed that early heading and early maturity in semi-arid locations are considered as indicators of increased tolerance to drought [19]. The interaction between irrigation treatments and cultivars on flowering time was highly significant (Table 3).

Days to maturity was also different among five irrigation treatments $(\mathrm{P}<0.01)$. The higher water stress levels (T1 and T2) caused earlier maturity (Table 4). Our research results indicated that cultivars that showed earlier heading showed earlier maturity, and they have a short grain-filling period (Table 5). Early heading and maturity have an advantage of allowing drought escape, enabling the cultivar to efficiently utilize irrigation or rainfall during critical growth stages. Drought stress caused 19- and 25-day acceleration in the maturity mean of 10 cultivars under T1 compared with control treatment (T5). Drought increases senescence by accelerating chlorophyll degradation, leading to a decrease in leaf area and photosynthesis. There is evidence that stay-green phenotypes with delayed leaf senescence can improve their performance under drought conditions [20].

Combined analyses of variance for grain-filling periods indicated the presence of highly significant differences among cultivars and irrigation treatments. Significant irrigation treatment $\times$ cultivar interaction was observed at $\mathrm{p}<0.05$ (Table 3 ). Drought stress at postanthesis reduce the grain-filling period, which will result in shriveled grains. During pre-anthesis growth, higher floret fertility is translated into a higher potential grain number per unit area [21], while grain weight depends on the degree to which post-anthesis conditions support grain-filling. Bread wheat genotypes with functional stay-green characteristics have also shown higher GY and total biomass in field conditions [22, 23]. In this study, GFP was different among five irrigation regimes $(\mathrm{P}<0.01)$, and the higher drought stress levels (T1, T2, and T3) caused a high reduction in the grain-filling period. The grain-filling rate is determined mostly by genetic factors and the grain-filling duration by environmental factors [24]. The shorter grain-filling duration may allow some avoidance of terminal stress while longer duration may allow greater utilization of stem reserves for grain filling under stress. Severe water stress from the seedling stage to maturity reportedly reduced all grain yield components - particularly the number of fertile ears per unit area by $60 \%$, grain number per head by $48 \%$, dry matter, and harvest index [21]. Lopes and Reynolds [25] reported that the improvement of cultivar yield under 
Table 4. Means comparison of irrigation treatments effects in studied traits, measured from 10 bread wheat.

\begin{tabular}{|c|c|c|c|c|c|c|c|c|c|c|}
\hline Irrigation Treatments & PH & DHE & DMA & GFP & NGS & TGW & HI & TDM & GWP & GY \\
\hline T1 & $79.54^{\mathrm{B}}$ & $137.2^{\mathrm{E}}$ & $163.3^{\mathrm{E}}$ & $26.08^{\mathrm{D}}$ & $38.81^{\mathrm{E}}$ & $34.93^{\mathrm{E}}$ & $36.60^{\mathrm{C}}$ & $6.94^{\mathrm{D}}$ & $2.305^{\mathrm{E}}$ & $1741^{\mathrm{E}}$ \\
\hline T2 & $91.37^{\mathrm{A}}$ & $143.2^{\mathrm{D}}$ & $173.0^{\mathrm{D}}$ & $29.85^{\mathrm{C}}$ & $39.60^{\mathrm{D}}$ & $36.70^{\mathrm{D}}$ & $37.47^{\mathrm{C}}$ & $8.09^{\mathrm{C}}$ & $2.715^{\mathrm{D}}$ & $2025^{\mathrm{D}}$ \\
\hline T3 & $94.47^{\mathrm{A}}$ & $149.1^{\mathrm{C}}$ & $178.9^{\mathrm{C}}$ & $29.88^{\mathrm{C}}$ & $45.31^{\mathrm{C}}$ & $37.92^{\mathrm{C}}$ & $40.75^{\mathrm{AB}}$ & $8.15^{\mathrm{AB}}$ & $3.363^{\mathrm{C}}$ & $2453^{\mathrm{C}}$ \\
\hline T4 & $94.79^{\mathrm{A}}$ & $155.2^{\mathrm{B}}$ & $190.0^{\mathrm{B}}$ & $34.85^{\mathrm{B}}$ & $55.52^{\mathrm{B}}$ & $41.43^{\mathrm{B}}$ & $39.80^{\mathrm{B}}$ & $8.25^{\mathrm{B}}$ & $3.734^{\mathrm{B}}$ & $3588^{\mathrm{B}}$ \\
\hline T5 & $94.91^{\mathrm{A}}$ & $156.3^{\mathrm{A}}$ & $192.8^{\mathrm{A}}$ & $36.53^{\mathrm{A}}$ & $56.23^{\mathrm{A}}$ & $41.98^{\mathrm{A}}$ & $42.20^{\mathrm{A}}$ & $9.66^{\mathrm{A}}$ & $4.333^{\mathrm{A}}$ & $4238^{\mathrm{A}}$ \\
\hline LSD 5\% & 5.20 & 0.72 & 0.98 & 1.36 & 2.61 & 0.54 & 1.50 & 0.95 & 0.18 & 170.20 \\
\hline
\end{tabular}

Drought stresses (no irrigation) introduced: rainfed (T1), the tillering stage (T2), at booting stage (T3), after anthesis (T4) and control treatment (T5). PH: Plant height; DHE: Day to Heading; DMA: Day to maturity; GFP: Grain filling period; NGS: Number of grain per spike; TGW: Thousand grain weight (gr); HI: Harvest index; TDM: Total dry matter; GWP: Grain weight per plant (gr); GY: Grain yield (kg/ha).

drought stress resulted from a more extended grainfilling duration.

The total dry matter was affected by drought stress introduced at $\mathrm{P} \leq 0.05$ (Table 3). The treatments $\mathrm{T} 1$ and T2 resulted in a reduction of total dry matter of 28.2 and $16.2 \%$, respectively, compared to control treatment. The lowest dry matter was found in T1. The results also revealed that drought stress did not affect total dry matter at T3 and T4 (Table 4). In comparison to the control (T5), plant height was significantly reduced at rainfed condition $(\mathrm{P} \leq 0.05)$ (Table 4). However, there was no significant difference between other treatments for plant height. The results revealed that at $\mathrm{T} 1$ they resulted in a $16 \%$ reduction in plant height compared to T5. At the severe water stress, all bread wheat cultivars were affected. It has been confirmed by many researchers that water stress leads to growth reduction, which was reflected in plant height, leaf area, dry weight, and other growth functions $[6,26]$. Plant height is the morphological characteristic associated with moving the carbohydrates, especially under stress conditions [16]. The reduction in plant height in response to drought stress can be due to the relative reduction of inflammation and water loss of the protoplasm, which contributes to the reduction of turgor pressure and cell division.

Combined analysis of variance showed that there was no significant difference between tiller numbers and fertile tillers number in irrigation treatment and cultivars (Table 3). The number of fertile stems is determined by weather conditions during the whole growing period - from emergence through tillering and stem elongation up to the stages of spike development. So much rain along earlier growing stages can make no signification difference in TN and FTN between irrigation treatments. The negative relationship between water stress conditions and either number of stems or number of spikes per $\mathrm{m}^{2}$ at maturity has also been reported for other wheat genotypes [27, 28-29].

The effect of drought stress on grain yield was highly significant at $(\mathrm{P} \leq 0.01)$ (Table 3 ). Some of the yield components were reduced by drought stress, which results in the reduction in grain yield.
The treatment drought stress in $\mathrm{T} 1, \mathrm{~T} 2, \mathrm{~T} 3$, and T4 result in the $15.35-58.92 \%$ reduction in grain yield as compared to T5. The highest grain yield (4238 $\mathrm{kg} \mathrm{ha}^{-1}$ ) was obtained from $\mathrm{T} 5$. This, the T4 treatment (3588 $\left.\mathrm{kg} \mathrm{ha}^{-1}\right)$, the T3 treatment $\left(2453 \mathrm{~kg} \mathrm{ha}^{-1}\right)$, and the T2 treatment $\left(2025 \mathrm{~kg} \mathrm{ha}^{-1}\right)$ followed. At least grain yield (1741 $\left.\mathrm{kg} \mathrm{ha}^{-1}\right)$ was obtained from the T1 treatment (rainfed condition). Compared to full-irrigation applications, the highest response to drought stress was obtained from the T1, with yield loss $58.92 \%$, followed by T2 (52.21\%) and T3 (42.13\%) treatments in order of decreasing, and with $15.35 \%$ the least response was determined in the T4. The results obtained in this study are consistent with research related to the impact of drought on grain yield in different stages of development [21]. Knowing that yield has two major components - grain number per unit area and grain weight - with grain number being determined during the pre-anthesis stage, while grain weight is determined at the post-anthesis stage, it is critical to study drought stress in the pre-anthesis (T1, T2, and T3) and postanthesis stages (T4).

The number of grains per spike and thousand grain weight were significantly $(\mathrm{P} \leq 0.01)$ influenced by irrigation treatments (Table 3). The lowest number of grains was found at $\mathrm{T} 1$. The reduction in the grain numbers from $\mathrm{T} 5$ to $\mathrm{T} 1$ was $31 \%$. This suggests that introducing drought stress can result in a serious reduction of grain numbers. Additionally, drought at the period of stem elongation causes a reduction in the number of grains per unit area due to its negative effect on floret formation and fertility. This reduction might be linked to reduction in plant growth that resulted in reduction in the capacity of source and sink size in drought-stressed plants compared to full-irrigation plants. Also, a decrease in photosynthetic rate due to pre-anthesis drought has been shown to be associated with a reduction in grain number [30]. Many reports have demonstrated that grain yield is more limited by grain number rather than grain weight in wheat and barley [30, 31].

The rainfed treatment (T1) produced significantly lower thousand-grain weight when compared with 
Table 5. Means comparison of 10 bread wheat cultivars effects in studied traits, measured from 5 irrigation treatments.

\begin{tabular}{|c|c|c|c|c|c|c|c|c|c|}
\hline Cultivars & PH & NGS & GWP & DHE & DMA & GFP & HI (\%) & TGW & GY \\
\hline C1 & $93.14^{\mathrm{B}}$ & $46.17^{\mathrm{A}-\mathrm{E}}$ & $3.241^{\mathrm{BCD}}$ & $144.8^{\mathrm{BC}}$ & $166.7^{\mathrm{AB}}$ & $31.6^{\mathrm{BC}}$ & $39.47^{\mathrm{B}}$ & $39.60^{\mathrm{A}}$ & $2603^{\mathrm{C}}$ \\
\hline $\mathrm{C} 2$ & $92.16^{\mathrm{B}}$ & $44.27^{\mathrm{EF}}$ & $3.217^{\mathrm{CD}}$ & $144.6^{\mathrm{C}}$ & $165.6 \mathrm{~A}^{\mathrm{BC}}$ & $31.5^{\mathrm{BC}}$ & $40.37^{\mathrm{AB}}$ & $39.37^{\mathrm{A}}$ & $2804^{\mathrm{ABC}}$ \\
\hline $\mathrm{C} 3$ & $91.64^{\mathrm{B}}$ & $45.33^{\mathrm{CDE}}$ & $3.369^{\mathrm{ABC}}$ & $144.7^{\mathrm{BC}}$ & $167.2^{\mathrm{A}}$ & $33.3^{\mathrm{B}}$ & $37.87^{\mathrm{D}}$ & $39.37^{\mathrm{A}}$ & $2760^{\mathrm{ABC}}$ \\
\hline C4 & $86.78^{\mathrm{C}}$ & $47.58^{\mathrm{AB}}$ & $3.412^{\mathrm{AB}}$ & $145.1^{\mathrm{B}}$ & $164.5^{\mathrm{C}}$ & $32.0^{\mathrm{BC}}$ & $40.33^{\mathrm{AB}}$ & $37.73^{\mathrm{B}}$ & $2795^{\mathrm{ABC}}$ \\
\hline C5 & $100.3^{\mathrm{A}}$ & $47.02^{\mathrm{ABC}}$ & $3.377^{\mathrm{ABC}}$ & $144.1^{\mathrm{C}}$ & $165.1^{\mathrm{BC}}$ & $30.2^{\mathrm{C}}$ & $41.27^{\mathrm{A}}$ & $37.70^{\mathrm{B}}$ & $2804^{\mathrm{ABC}}$ \\
\hline C6 & $85.78^{\mathrm{C}}$ & $45.60^{\mathrm{B}-\mathrm{E}}$ & $3.116^{\mathrm{D}}$ & $144.9^{\mathrm{BC}}$ & $166.5^{\mathrm{AB}}$ & $31.1^{\mathrm{BC}}$ & $38.40^{\mathrm{C}}$ & $38.37^{\mathrm{AB}}$ & $2821^{\mathrm{AB}}$ \\
\hline C7 & $85.34^{\mathrm{C}}$ & $46.65^{\mathrm{A}-\mathrm{D}}$ & $3.122^{\mathrm{D}}$ & $146.2^{\mathrm{ABC}}$ & $166.4^{\mathrm{AB}}$ & $30.5^{\mathrm{C}}$ & $38.07^{\mathrm{CD}}$ & $37.77^{\mathrm{B}}$ & $2753^{\mathrm{BC}}$ \\
\hline C8 & $82.99^{\mathrm{D}}$ & $43.28^{\mathrm{F}}$ & $3.222^{\mathrm{BCD}}$ & $146.9^{\mathrm{A}}$ & $166.2 \mathrm{~A}^{\mathrm{BC}}$ & $30.8^{\mathrm{C}}$ & $40.67^{\mathrm{AB}}$ & $38.70^{\mathrm{AB}}$ & $2937^{\mathrm{AB}}$ \\
\hline C9 & $93.60^{\mathrm{B}}$ & $44.92^{\mathrm{DEF}}$ & $3.294^{\mathrm{BCD}}$ & $146.6^{\mathrm{AB}}$ & $165.1^{\mathrm{BC}}$ & $35.3^{\mathrm{A}}$ & $39.03^{\mathrm{BC}}$ & $38.63^{\mathrm{AB}}$ & $2960^{\mathrm{A}}$ \\
\hline C10 & $98.43^{\mathrm{A}}$ & $48.11^{\mathrm{A}}$ & $3.530^{\mathrm{A}}$ & $146.3^{\mathrm{ABC}}$ & $166.9^{\mathrm{AB}}$ & $35.0^{\mathrm{AB}}$ & $38.17^{\mathrm{CD}}$ & $38.70^{\mathrm{AB}}$ & $2854^{\mathrm{AB}}$ \\
\hline LSD $5 \%$ & 2.303 & 2.028 & 0.1906 & 0.936 & 0.867 & 1.349 & 2.206 & 0.7014 & 202.8 \\
\hline
\end{tabular}

PH: Plant height; NGS: Number of grain per spike; GWP: Grain weight per plant (gr); DHE: Day to Heading; DMA: Day to maturity; GFP: Grain filling period; HI: Harvest index; TGW: Thousand grain weight (gr); GY: Grain yield (kg/ha).

the control treatment (Table 4). The results showed significant differences $(\mathrm{p}<0.01)$ among cultivars in the TGW (Table 5). G1, G2, and G3 produced the highest grain weights $(39.60,39.37$, and $39.37 \mathrm{~g}$, respectively), while G4, G5, and G7 produced the lowest (37.70, 37.73, and $37.77 \mathrm{~g}$, respectively). There was also a significant irrigation treatment $\times$ cultivar interaction $(p<0.01)$ for TGW. The compared means for cross treatment showed that G10 and G9 (irrigation cultivars) in T5 have the highest and G7 and G9 in T1 have the lowest TGW. During pre-anthesis growth, higher floret fertility is translated into a higher potential grain number per unit area, while grain weight depends on the degree to which post-anthesis conditions support grain-filling. In such cases, drought at the pre-anthesis stage can have greater yield reductions than in post-anthesis stages of growth, because it affects yield potential at the sink level via decreasing the number of fertile spikes per unit area at crop establishment and tillering phases, as well as the number of grains per spike.

The current study found a significant reduction in grain weight per plant due to pre-anthesis water stress (T1, T2, and T3). This was consistent with findings of $[32,33]$. Roman et al. [21] found that final grain weight was reliant on carpel weight at anthesis. The expected reason for reduction in grain weight in drought stress treatments might be due to drought influencing the emergent florets and lessening the weight of the carpel at pollination. a)

U

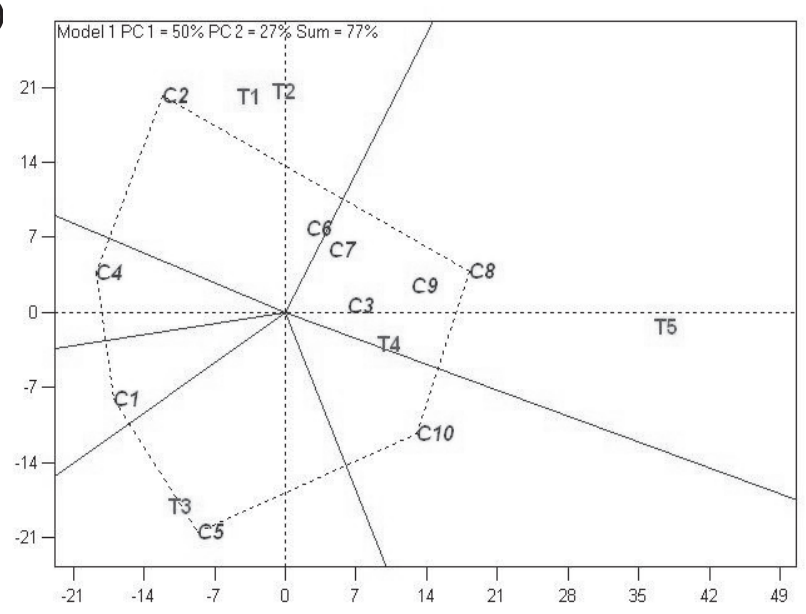

b)

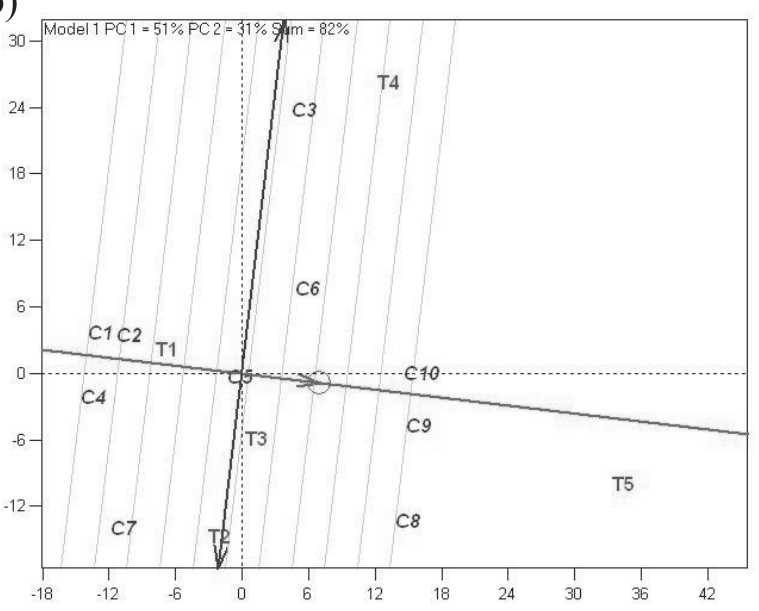

PC1

Fig. 1. a) Mega-environment and their winning cultivars, b) cultivar rankings based on both average yield and stability. 
Hence, although late emerged tillers contribute less to grain yield than do tillers that emerged earlier, there still exists a possibility for plant re-growth after drought stress abating, and it is considered one of the implications of adaptation responses to perception.

In a plant breeding program, potential cultivars are usually evaluated in different environments before selecting desirable ones that show stability across environments. The major objective of plant breeders in a crop-breeding program is the development of cultivars, or cultivars that are stable or adapted to a wide range of diversified environments. During the growth stages, plants may be exposed to drought stress. Therefore, the cultivars will be better when highly stable and able to produce good performance in these conditions.

Yield stability has been extensively studied by biometricians, and various methods have been developed. The GGE-Biplot methodology [34] provides a powerful solution for studying stability. Biplot analysis is a multivariate analytical technique that graphically displays the two-way data and allows visualization of the interrelationship among environments, and the interrelationship between cultivars and environments. Biplots are useful in summarizing and approximating patterns of response that exist in the original data [35].

There are numerous ways to use a GGE-Biplot, but the polygon view of the biplot is most relevant to the mega-environments identification. For this purpose, the cultivars are connected with straight lines so that a polygon is formed with all other cultivars contained within the polygon (Fig. 1a). The vertex cultivars (G2, G8, G10, G5, G1, and G4) are the best or the poorest cultivars in some or all of the environments since they had the longest distance from the origin of biplot. There are six sectors in Fig. 1a). The vertex cultivar for each sector is the one that gave highest yield for environments that fall within that sector. Therefore, the first group contained $\mathrm{T} 1$ and $\mathrm{T} 2$, with cultivar G2 being the winner. Cultivar G8 gave the highest performance in $\mathrm{T} 4$ and $\mathrm{T} 5$, and cultivars G5 gave the highest performance in environment T3. Cultivars G1, G10, and G4 did not gave the highest yield in any of the environments.

Other applications of the GGE biplot methodology are to visually identify the mean performance and stability of cultivars. The mean yield of the cultivars can then be approximated by nominal yields of the cultivars in the mean environments. In Fig. 1b), cultivars G8, G9, and G10 had the highest mean yields, and cultivars G1 AND G4 had the poorest.

A cultivar is more stable if it is closer to axis Y. Therefore, the performance of cultivars G3, G7, and G8 are highly variable (less stable), whereas cultivars G5, G1, G2, G10, G9, and G4 are highly stable. An ideal cultivar is one that has both high mean yield and high stability. Therefore, cultivars G9 and G10 are more desirable than other cultivars. For more information about the GGE-Biplot software, see Yan and Kang [34].

\section{Conclusions}

Although drought stress affects most of the functions of plant growth, this effect depends on the level of water stress, the length of time to which the plant is subjected to water stress, and the genotype of the plan. It is clear from the results obtained in this study that different levels of water stress affect the growth of wheat cultivars differently, which indicates that the wheat cultivars differed in their ability to tolerate different levels of water stress. This will help to discover more growth and physiological parameters that might be related to drought stress sensitivity. Many researchers have confirmed that water stress leads to growth reduction, which is reflected in plant height, dry matter, and other growth functions.

\section{Acknowledgements}

The authors wish to express their sincere thanks to the Dryland Agricultural Research Institute (DARI), AREEO, Maragheh, Iran, for their assistance in facilitating the present research study.

\section{Conflict of Interest}

The authors declare no conflict of interest.

\section{References}

1. PORTMANN F.T., SIEBERT S., DÖLL P. MIRCA2000 Global monthly irrigated and rainfed crop areas around the year 2000: a new high-resolution data set for agricultural and hydrological modeling Glob. Biogeochem. Cycles 24 GB1011. 2010.

2. LOBELL D.B., GOURDJI S.M. The influence of climate change on global crop productivity. Plant Physiol. 160, 1686, 2012.

3. SHIFERAW B., et al. Crops that feed the world 10. Past successes and future challenges to the role played by wheat in global food security Food Sec. 5, 291, 2013.

4. BEN-ARI T., MAKOWSKI D. Decomposing global crop yield variability Environ. Environmental Research Letters, 9, 11, 2014.

5. F.A.O. Statistical database. Available online: $\mathrm{Http} / / \mathrm{www}$. FAO. Org. 2016.

6. BUDAK H., KANTAR M., KURTOGLU K.Y. Drought tolerance in modern and wild wheat. Scientific World Journal. 2013.

7. FARSHADFAR E., RASHIDI M., MAHDI M.J., ZALI H. GGE biplot analysis of genotype $\times$ environment interaction in chickpea genotypes. Eur. J. Exp. Biol. 3, 417, 2013.

8. EMAM Y., SHEKOOFA A., SALEHI F., JALALI A.H. Water stress effects on two common bean cultivars with contrasting growth habits. Am. Eurasian J. Agric. Environ. 9, 495, 2010.

9. HAWKESFORD M., ARAUS J., PARK R., CALDERINI D., MIRALLES, D., SHEN T., et al. Prospects of doubling global wheat yields. Food Energy Secure. 2, 34, 2013. 
10. NOURI A., ETMINAN A., TEIXEIRADASILVA J.A., MOHAMMADI R. Assessment of yield, yield-related traits and drought tolerance of durum wheat genotypes (Triticum turjidum var. durum Desf.). Aust.J.CropSci. 5, 8, 2011.

11. MANIVANNAN P., JALEEL C.A., SOMASUNDARAM R., PANNEERSELVAM R. Osmoregulation and antioxidant metabolism in drought-stressed Helianthus annuus under triadimefon drenching. C R Biologies. 331, 418, 2008.

12. LI YP., YE W., WANG M., YAN X.D. Climate change and drought: a risk assessment of cropyield impacts. Climate Res. 39, 31, 2009.

13. DEMIREVSKA K., ZASHEVA D., DIMITROV R., SIMOVA-STOILOVA L., STAMENOVA M., FELLER U. Drought stress effects on Rubisco in wheat: changes in the Rubisco large subunit. Acta Physiol Plant, 31, 1129, 2009.

14. BLUM A., SHPILER L., GOLAN A., MAYER J. Yield Stability and Canopy Temperature of Wheat Genotypes under Drought Stress. Field Crop Res, 22 (41), 289, 1989.

15. FRANCIA E., TONDELLI A., RIZZA F., BADECK F.W., THOMAS W.T.B., VAN EEUWIJK ROMAGOSA I., STANCA A.M., PECCHIONI N. Determinants of barley grain yield in drought-prone Mediterranean environments. Italian Journal of Agronomy. 8 (1), 1, 2013.

16. HOSSAIN A., TEIXEIRA DA SILVA J.A., LOZOVSKAYA M.V., ZVOLINSKY V.P., MUKHORTOV V.I. High temperature combined with drought affect rainfed spring wheat and barley in southeastern Russia: Yield, relative performance and heat susceptibility index. Journal of Plant Breeding and Crop Science. 4 (11), 184, 2012.

17. FAROOQ M., WAHID A., KOBAYASHI N., FUJITA D., BASRA S.M.A. Plant drought stress: effects, mechanisms and management. Agronomy for Sustainable Development. 29, 185, 2009.

18. SAS Institute. The SAS system for Windows. Release 9.16. SAS Inst., Cary, NC. 2016.

19. BILAL M., RASHID RM., REHMAN SU., IQBAL F., AHMED J., ABID MA., AHMED Z., HAYAT A. Evaluation of wheat genotypes for drought tolerance. Journal of green physiology, genetics and genomics 1, 11, 2015.

20. NEZHADAHMADI A., PRODHAN Z., FARUQ G. Drought Tolerance in Wheat. The Scientific World Journal. 13, 1, 2013.

21. GONZALEZ A., BERMEJO V., GIMENO B.S. Effect of different physiological traits on grain yield in bar-ley grown under irrigated and terminal water deficit conditions. J. Agric. Sci. 148, 319, 2010.

22. CALDERINI D.F., REYNOLDS M.P. Changes in grain weight as a consequence of de-graining treatments at preand post-anthesis in synthetic hexaploid lines of wheat (Triticum durum^T. tauschii). Aust. J. Plant Physiol. 27, 183, 2000.

23. CHEN J.B., LIANG Y., HU X.Y., WANG X.X., TAN F.Q., ZHANG H.Q., et al. Physiological characterization of stay green wheat cultivars during the grain filling stage under field growing conditions. ActaPhysiol.Plant. 32, 875, 2010.

24. RAJALA A., HAKALA K., MÄKELÄ P., PELTONENSAINIO P. Drought effect on grain number and grain weight at spike and spikelet level in six-row spring barley. J. Agron. Crop Sci. 197, 103, 2011.

25. LOPES M.S., REYNOLDS M.P. Stay-green in spring wheat can be determined by spectral reflectance measurements (normalized difference vegetation index) independently from phenology. J.Exp.Bot. 63, 3789, 2012.

26. KILIC H., YAĞBASANLAR T. The effect of drought stress on grain yield, yield components and some quality traits of durum wheat (Triticum turgidum) cultivars. Notulae Botanicae Horti Agrobotanici Cluj-Napoca 38: 164, 2010.

27. DRECCER M., VAN HERWAARDEN A., CHAPMAN S. Grain number and grain weight in wheat lines contrasting for stem water soluble carbohydrate concentration. Field Crop. Res. 112, 43, 2009.

28. DRECCER M.F., CHAPMAN S.C., RATTEY A.R., NEAL J., SONG Y., CHRISTOPHER J.T., et al. Developmental and growth controls of tillering and water-soluble carbohydrate accumulation in contrasting wheat (Triticum aestivum L.) genotypes: can we dissect them? J.Exp.Bot. 64, 143, 2013.

29. REBETZKE G.J., VAN HERWAARDEN A.F., JENKEINS C., WEISS., LEWIS D., RUUSKA S., et al. Quantitative trait loci for water-soluble carbohydrates and associations with agronomic traits in wheat. Aust.J.Exp.Agric. 59, 891, 2008.

30. FRANCIA E., TONDELLI A., RIZZA F., BADECK F., LI DESTRI NICOSIA O., AKAR T., GRANDO S., AL-YASSIN A., BENBELKACEM A., THOMAS W. Determinants of barley grain yield in a wide range of Mediterranean environments. Field Crop. Res. 120, 169, 2011.

31. ROMÁN A., SERRAGOA, I. A., ROXANA S., GUSTAVO A. Slafer: Understanding grain yield responses to source sink ratios during grain filling in wheat and barley under contrasting environments. Field Crops Research. 2013.

32. ARISNABARRETA S., MIRALLES D.J. Critical period for grain number establishment of near isogenic lines of two- and six-rowed barley. Field Crop. 107, 196, 2008.

33. LIZANA X., CALDERINI D. Yield and grain quality of wheat in response to increased temperatures at key periods for grain number and grain weight determination: Considerations for the climatic change scenarios of Chile. J. Agric. Sci. 151, 209, 2013.

34. YAN W., KANG M.S. Ggebiplot Analysis: A Graphical Tool for Breeders. Geneticists, and Agronomists, CRD Press. Boca Raton. 2003.

35. EBADI SEGHERLOO A., SABAGHPOUR S.H., DEHGHANI H., KAMRANI M. Screening of superior chickpea genotypes for various environments of Iran using genotype plus genotype $\times$ environment (GGE) biplot analysis. Journal of Plant Breeding and Crop Science. 2 (9), 286, 2010. 